\title{
Human Salivary Acidic Proline-Rich Proteins (APRP-1/2) In Adult Patients With Dental Caries
}

\author{
Anna K Szkaradkiewicz-Karpińska ${ }^{1}$, Marta Sak ${ }^{2}$, Olga Goślińska-Kuźniarek ${ }^{2}$, Jerzy Sokalski ${ }^{3}$ and Andrzej Szkaradkiewicz ${ }^{\star}$ \\ ${ }^{1}$ Department of Conservative Dentistry and Periodontology, University of Medical Sciences in Poznan, Poland \\ ${ }^{2}$ Department of Medical Microbiology, University of Medical Sciences in Poznan, Poland \\ ${ }^{3}$ Department of Dental Surgery, University of Medical Sciences in Poznan, Poland
}

"Corresponding author: Andrzej Szkaradkiewicz, Department of Medical Microbiology, University of Medical Sciences in Poznan, Wieniawskiego 3 Street, Poznan, Poland, Tel.: +48 618546 138; Fax: +48 618546 140; E-mail: szkaradkiewicza@poczta.onet.pl

Recieved Date: May 10, 2017; Accepted Date: May 23, 2017; Published Date: May 26, 2017

Copyright: (C) 2017 Szkaradkiewicz-Karpińska AK, et al. This is an open-access article distributed under the terms of the Creative Commons Attribution License, which permits unrestricted use, distribution, and reproduction in any medium, provided the original author and source are credited.

\begin{abstract}
Background: Acidic proline-rich proteins (APRPs) are manifested in human saliva in various phenotypes and represent its important component. The unique structure of their two isoforms. APRP-1/2 as well as their coupling to hydroxyapatite and formation of the acquired enamel pellicle are well known. Nevertheless, role of APRP-1/2 in adult patients with dental caries still remains unclear. The aim of this study was to analyze the levels of APRP-1/2 in saliva of adult patients with dental caries.
\end{abstract}

Patients and Methods: The studies were conducted on 106 adult patients which were qualified to individual groups on grounds of dental examination and calculation of DMFT index. Group 1 (control) included 18 caries-free patients $(\mathrm{DMFT}=0)$ ). Group 2 included 20 persons (DMFT=2.3 \pm 1.0 ) with very low intensity of caries. Group 3 included 20 patients (DMFT=6.2 \pm 1.3 ) with low intensity of caries. Group 4 comprised 24 patients (DMFT=10.9 \pm 1.8) with moderate intensity of caries. Group 5 included 24 patients (DMFT=19.5 \pm 3.5 ) with high intensity of dental caries. Concentrations of APRP-1/2 in saliva were estimated using PRH2 ELISA kit (MyBioSource).

Results: In persons of group 1 (control) concentration of APRP-1/2 averaged at $15.2 \pm 2.6 \mathrm{ng} / \mathrm{ml}$. This concentration did not statistically differ from results obtained in patients of groups 2 . On the other hand in patients of groups 3, 4 and 5 mean values of APRP-1/2 concentrations amounted respectively to: $18.6 \pm 3.2 \mathrm{ng} / \mathrm{ml}, 35.4 \pm 4.6$ $\mathrm{ng} / \mathrm{ml}$ and $39.8 \pm 5.1 \mathrm{ng} / \mathrm{ml}$. The obtained values of APRP-1/2 were significantly higher than results obtained in group 1 ( $p<0.05$; Mann-Whitney test). In parallel the numerical force of women and men examined in the distinguished groups manifested no significant differences ( $p>0.05$; test for two independent proportions).

Conclusions: High levels of APRP-1/2 in saliva of adult patients may be involved in intensification of the caries process.

Keywords: Oral health; Dental health; Saliva; Salivary proline-rich proteins; Dental caries

\section{Introduction}

Acidic proline-rich proteins (APRPs) accounting for $20-30 \%$ of all human salivary proteins are secreted by both parotid and submandibular/sublingual glands [1]. APRPs belong to the highly unique family of proline-rich proteins - PRP, characterized by high proline content ( 25 to $42 \%$ of total amino acids), which affects protein conformation with a prominent preference of $\beta$-sheet structure $[2,3]$. Currently, a group of 10 distinct APRPs can be distinguished (APRP-1/2, APRP-3/4, parotid isoelectric-focusing slow/fast variantPIF-s/f, parotid acidic protein - Pa, the double-band slow/fast isoform- $\mathrm{Db}-\mathrm{s} / \mathrm{f}$ and PC peptide), encoded by two genetic loci, PRH1 and $\mathrm{PRH} 2$ on chromosome 12 at p13.2 [4]. The PRH2 locus has two alleles and is responsible for the synthesis of principal isoforms of APRP-1/2 representing precursors of APRP-3/4 [3,5]. The PRH1 locus has three different alleles encoding the PIF-s, $\mathrm{Pa}$ and Db-s isoforms [5]. Despite studies, recently also those with application of proteomics, the role of different APRP phenotypes, and particularly of APRP-3/4. PIF-f and Db-f in oral cavity continues to be unclear. In turn, it is well known that APRP-1/2 manifest high affinity for hydroxyapatite and are involved in the formation of dental-acquired pellicle [6-8]. It is also suggested that salivary APRPs may affect susceptibility to dental caries [9].

Therefore, the currently undertaken study aimed at obtaining data on the range of APRP-1/2 quantitative alterations in full unstimulated saliva of adult patients as compared to intensity of dental caries.

\section{Patients and Methods}

\section{Patients grouping}

The studies were conducted on 106 patients, 20-35 years of age, which were qualified to individual groups on grounds of dental examination and calculation of DMFT (Decayed Missing and Filled Teeth) index. Evaluation of caries intensity took into account the obtained values of DMFT index, in line with the WHO criteria [10], presented in Table 1. 


\begin{tabular}{|l|l|}
\hline DMFT Index & Caries Experience \\
\hline $1-4.9$ & Very Low \\
\hline $5-8.9$ & Low \\
\hline $9-13.9$ & Moderate \\
\hline$>13.9$ & High \\
\hline
\end{tabular}

diseases, bruxism, alcoholism and smoking of cigarettes. Within three weeks preceding the study, the patients were not subjected to hygienization procedures or to use of anti-bacterial mouth washes.

\section{Ethical approval and consent to participate}

This study was approved by the Medical Ethics Committee at the University of Medical Sciences in Poznań, Poland. All subjects gave written informed consent in accordance with the Declaration of Helsinki.

Table 1: Criteria of dental caries intensity.

Group 1 (control) included 18 caries-free patients (20-26 years of age; 10 women and 8 men; DMFT=0). In none patient of the group detectable caries or fillings were detected. The remaining groups included patients with dental caries. Group 2 included 20 persons (20-32 years of age; 12 men and 8 women; DMFT $=2.3 \pm 1.0)$ with very low intensity of caries. Group 3 included 20 patients (21-35 years of age; 11 men and 9 women; DMFT=6.2 \pm 1.3 ) with low intensity of caries. Group 4 comprised 24 patients (20-35 years of age; 15 men and 9 women; DMFT $=10.9 \pm 1.8$ ) with moderate intensity of caries. Group 5 included 24 patients (20-35 years of age; 14 men and 10 women; $\mathrm{DMFT}=19.5 \pm 3.5$ ) with high intensity of dental caries.

\begin{tabular}{|c|c|c|c|c|}
\hline Groups & $\begin{array}{l}\text { DMFT index } \\
\text { Mean values } \pm \\
\text { SD }\end{array}$ & P-value & $\begin{array}{l}\text { Salivary } \\
\text { APRP-1/2 } \\
\text { Mean values in } \\
\mathrm{ng} / \mathrm{ml} \pm \mathrm{SD}\end{array}$ & P-value \\
\hline $1 \& 2$ & $\begin{array}{l}0 \\
2.3 \pm 1.0\end{array}$ & $<0.001$ & $\begin{array}{l}15.2 \pm 2.6 \\
15.9 \pm 2.1\end{array}$ & $\begin{array}{l}\text { Ns } \\
(p=0.355)\end{array}$ \\
\hline $1 \& 3$ & $\begin{array}{l}0 \\
6.2 \pm 1.3\end{array}$ & $<0.001$ & $\begin{array}{l}15.2 \pm 2.6 \\
18.6 \pm 3.2\end{array}$ & $<0.001$ \\
\hline $1 \& 4$ & $\begin{array}{l}0 \\
10.9 \pm 1.8\end{array}$ & $<0.001$ & $\begin{array}{l}15.2 \pm 2.6 \\
35.4 \pm 4.6\end{array}$ & $<0.001$ \\
\hline $1 \& 5$ & $\begin{array}{l}0 \\
19.5 \pm 3.5\end{array}$ & $<0.001$ & $\begin{array}{l}15.2 \pm 2.6 \\
39.8 \pm 5.1\end{array}$ & $<0.001$ \\
\hline $2 \& 3$ & $\begin{array}{l}2.3 \pm 1.0 \\
6.2 \pm 1.3\end{array}$ & $<0.001$ & $\begin{array}{l}15.9 \pm 2.1 \\
18.6 \pm 3.2\end{array}$ & $<0.004$ \\
\hline $2 \& 4$ & $\begin{array}{l}2.3 \pm 1.0 \\
10.9 \pm 1.8\end{array}$ & $<0.001$ & $\begin{array}{l}15.9 \pm 2.1 \\
35.4 \pm 4.6\end{array}$ & $<0.001$ \\
\hline $2 \& 5$ & $\begin{array}{l}2.3 \pm 1.0 \\
19.5 \pm 3.5\end{array}$ & $<0.001$ & $\begin{array}{l}15.9 \pm 2.1 \\
39.8 \pm 5.1\end{array}$ & $<0.001$ \\
\hline $3 \& 4$ & $\begin{array}{l}6.2 \pm 1.3 \\
10.9 \pm 1.8\end{array}$ & $<0.001$ & $\begin{array}{l}18.6 \pm 3.2 \\
35.4 \pm 4.6\end{array}$ & $<0.001$ \\
\hline $3 \& 5$ & $\begin{array}{l}6.2 \pm 1.3 \\
19.5 \pm 3.5\end{array}$ & $<0.001$ & $\begin{array}{r}18.6 \pm 3.2 \\
39.8 \pm 5.1\end{array}$ & $<0.001$ \\
\hline $4 \& 5$ & $\begin{array}{l}10.9 \pm 1.8 \\
19.5 \pm 3.5\end{array}$ & $<0.001$ & $\begin{array}{l}35.4 \pm 4.6 \\
39.8 \pm 5.1\end{array}$ & $<0.01$ \\
\hline
\end{tabular}

Table 2: Comparison between groups in the means \pm standard deviations of the DMFT and salivary APRP-1/2.

The patients qualified to the studies were generally healthy, with no general or chronic diseases in anamnesis. Moreover, the exclusion criteria included fungal infection in oral cavity, destructive periodontal

\section{Salivary sample collection}

Saliva was collected by the standard method. Samples from the subjects were collected between 8:00 and 11:00 a.m. All subjects abstained from eating and drinking for $2 \mathrm{~h}$. Unstimulated whole saliva was collected for $10 \mathrm{~min}$ by a spitting method. Saliva samples were homogenized and clarified by centrifugation at $3.000 \times \mathrm{g}$ for $15 \mathrm{~min}$ at $4^{\circ} \mathrm{C}$. The aliquots of clarified supernatants were stored at $-70^{\circ} \mathrm{C}$ for the APRP-1/2 measurements.

\section{Determination of APRP-1/2}

Salivary APRP-1/2 were quantitated using an immunoenzymatic technique (ELISA). The PRH2 ELISA kit (MyBioSource, San Diego) was applied, manifesting high specificity for detection of salivary APRP-1/2 and high sensitivity: $0.55 \mathrm{ng} / \mathrm{ml}$. The tests were performed as recommended by the manufacturer. Values of absorbance depending on estimated APRP-1/2, were read at the wavelength of $\mathrm{A}=450 \mathrm{~nm}$ using Reader 250 (bioMerieux). The results were obtained from standard curves. Every estimation of salivary APRP-1/2 was repeated three times and the obtained mean represented individual result for the patient.

\section{Data analysis}

The results obtained in the studies were analyzed using the Statistica v.12 software. In the comparative analysis of salivary APRP-1/2 levels in the studied groups the nonparametric Mann-Whitney test was used. In analysis of shares of examined women and men the test for two independent proportions was used.

Differences with P-values higher than 0.05 were considered nonsignificant.

\section{Results}

APRP-1/2 was detected in full unstimulated saliva in all the examined groups; the results are listed in Table 2.

In group 1 of caries-free individuals concentration of APRP-1/2 averaged at $15.2 \pm 2.6 \mathrm{ng} / \mathrm{ml}$. In turn, in patients with dental caries salivary concentration of APRP-1/2 was analyzed in the context of caries intensity, expressed by values of DMFT-index. The obtained mean values of DMFT-index in the distinguished groups of patients proved to be statistically distinct and amounted to, respectively: group $1-0$; group 2-2.3 \pm 1.0 ; group 3-6.2 \pm 1.3 ; group $4-10.9 \pm 1.8$ and group 5-19.5 \pm 3.5. In turn, mean levels of salivary APRP $1 / 2$ in individual groups of patients amounted to, respectively. $15.2 \pm 2.6 \mathrm{ng} / \mathrm{ml}$ in group $1 ; 15.9 \pm 2.1 \mathrm{ng} / \mathrm{ml}$ in group $2 ; 18.6 \pm 3.2 \mathrm{ng} / \mathrm{ml}$ in group $3 ; 35.4 \pm 4.6$ $\mathrm{ng} / \mathrm{ml}$ in group 4 and $39.8 \pm 5.1 \mathrm{ng} / \mathrm{ml}$ in group 5 . Comparative analysis of the mean APRP-1/2 values between individual studied groups disclosed significant differences except of the absence of 
statistical significance between groups 1 and 2. The results are listed in Table 2. Moreover, the obtained results allowed to draw the exponential curve of dependence between DMFT index and APRP1/2 (Figure 1).

In turn, analysis of numerical forces manifested by studied women and men in the distinguished groups demonstrated no statistically significant differences $(\mathrm{p}>0.05)$.

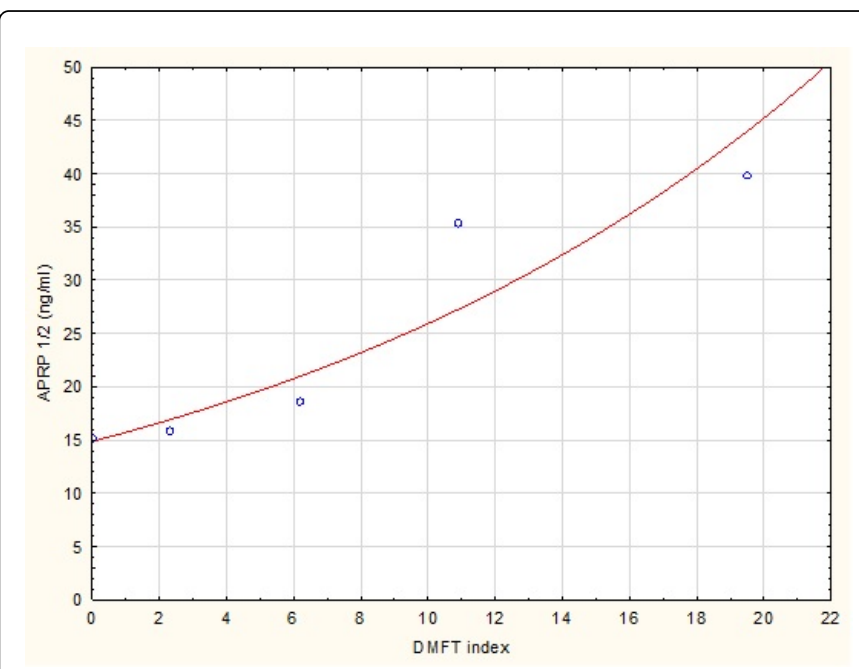

Figure 1: Exponential curve of dependence between DMFT and APRP1/2. Each circle represents mean of results in studied group.

\section{Discussion}

Dental caries is the most common infectious disease and affects approximately $36 \%$ of the population in the world; it is characterized by demineralization and destruction of dental hard tissues, such as enamel dentin and cement $[11,12]$. This local pathological process represents the most frequent cause of dental loss in adults [13]. Dental caries is caused by cariogenic bacteria, particularly oral streptococci within the produced on the acquired enamel pellicle of a dentally adherent biofilm (plaque) in the presence of dietary carbohydrates and sucrose in particular [14]. In etiology of dental caries the central role is played by Streptococcus mutans, because it can adhere to the pellicle and to other plaque bacteria [15]. Strains of this bacterial species are highly acidogenic. They produce short-chain acids which can dissolve hard tissues of teeth. Moreover, in the presence of sucrose they are able to form large quantities of water-insoluble extracellular polysaccharides (EPS), which, manifesting adherente properties, are responsible for plaque progress. Development of dental biofilm may reflect also action of mutacins (bacteriocins), produced by strains of $S$. mutans $[16,17]$. Thus, as indicated by the presented data the developed on dental surface the acquired pellicle, incorporating cariogenic bacteria via specific cell-to-surface interactions, represents an essential factor in initiation of caries-developmental process. It has already been well documented that this pellicle is formed by adsorption of proteins from the fluid surrounding the teeth [1]. Using the extraction procedure APRPs have been demonstrated to provide a major component of the new, in the first hour formed acquired pellicle $[7,18]$. Nevertheless, from the beginning of its existence a degradation process develops of the adsorbed proline-rich proteins, which may explain the minimum content of APRPs in pellicles more than 24 hours old [1].
Structural studies indicate that APRP-1/2 include two positional isoforms, every involving a single polypeptide chain, which consists of 150 residues $[1,19]$. Its $\mathrm{N}$-terminal domain consists of 30 residues, including the two phosphoserines but only one proline. In turn, the sequence from residue 31 to the $\mathrm{C}$-domain represents a proline-rich region, including repeats high in proline glycine and glutamine. At present, the unique structure of APRP-1/2 is thought to determine its specific properties. The $\mathrm{N}$-terminal domain ensures coupling of APRP-1/2 to hydroxyapatite and formation of the acquired enamel pellicle. In parallel the C-terminal domain of APRP-1/2 binds to oral bacteria, promoting bacterial colonization of dental surface, which may play a significant role in pathogenesis of caries $[9,20]$.

The conducted studies failed to detect significant differences in levels of APRP-1/2 in unstimulated saliva obtained from patients free of dental caries (group 1) and from persons with very low (group 2) intensity of caries. Therefore, the manifestation of dental caries might be suggested to remain not linked to alterations in APRP-1/2 concentrations in saliva of adult patients. Such suggestion is consistent with earlier studies indicating absence of significant differences between values of salivary APRP in caries-resistant patients and cariessusceptible patients [21]. However, such results were obtained for stimulated saliva using visual radial immunodiffusion assay. In contrast, in our work we employed the highly semsitive and specific ELISA test [22]. Moreover, no patients in studied groups reported an excessive consumption of carbohydrates, all of them manifested similar alimentary habits and oral hygiene procedures which, therefore, could not significantly affect manifestation of dental caries in any of studied groups. However, manifestation and progression of dental caries reflects not only environmental conditioning but also genetic influences, as demonstrated in studies on humans and in animal models. In parallel, $45-64 \%$ of caries susceptibility has been shown to be genetically determined [23]. A significant association was reported between human caries and genes coding amelogenin (AMELX), ameloblastin (AMBN) and tuftelin (TUFT) [24]. The genes are of key importance for enamel formation. Such data may explain absence of caries in persons of group 1 and its variable intensity in the remaining groups of patients. Nevertheless, in persons with low (group 3), moderate (group 4) and high (group 5) intensity of dental caries which have demonstrated significantly higher levels of salivary APRP-1/2 than in group 1. The results, presented for the first time in this study, allow to conclude that elevated levels of APRP-1/2 may cooperate in development of dental caries in adults. This conclusion, at least in part may be corroborated by studies pointing to a relationship between development of dental caries on one hand and genetic polymorphism in PRH1 and PRH2 loci [24,25].

In light of presented data it can be concluded that levels of APRP-1/2 in saliva of adult patients may exert an effect on origin and development of dental caries.

\section{Conclusions}

Our study demonstrated the possible connections between intensity of dental caries in adults and the concentration of salivary acidic-rich proteins, APRP-1/2. Knowledge on manifestation of quantitative alterations in the salivary components allows to explain their involvement in pathogenesis of dental caries. Future research is essential to more completely characterize function of salivary acidicrich protein phenotypes in the caries process. 
Citation: Szkaradkiewicz-Karpinska AK, Sak M, Goslinska-Kuzniarek O, Sokalski J, Szkaradkiewicz J (2017) Human Salivary Acidic Proline-Rich Proteins (APRP-1/2) In Adult Patients With Dental Caries. Dentistry 7: 437. doi:10.4172/2161-1122.1000437

Page 4 of 4

\section{Acknowledgment}

The research was supported by University of Medical Sciences in Poznań, Poland (504-01-02206316-7/109).

\section{References}

1. Bennick A (1982) Salivary proline-rich proteins. Mol Cell Biochem 45:83-99.

2. MacArthur MW, Thornton JM (1991) Influence of proline residues on protein conformation. J Mol Biol 218: 397-412.

3. Inzitari R, Cabras T, Onnis G, Olmi C, Mastinu A, et al. (2005) Different isoforms and post-translational modifications of human salivary acidic proline-rich proteins. Proteomics 5: 805-815.

4. Manconi B, Castagnola M, Cabras T, Olianas A, Vitali A, et al. (2016) The intriguing heterogeneity of human salivary proline-rich proteins. J Proteomics 134:47-56.

5. Kim HS, Smithies O, Maeda N (1990) A physical map of the human salivary proline-rich protein gene cluster covers over $700 \mathrm{kbp}$ of DNA. Genomics 6: 260-267.

6. Moreno EC, Kresak M, Hay DI (1982) Adsorption thermodynamics of acidic proline-rich human salivary proteins onto calcium apatites. J Biol Chem 257: 2981-2989.

7. Bennick A, Chan G, Goodlin R, Abcrams S, Tustian D, et al. (1983) The role of human salivary acidic proline-rich proteins in the formation of acquired dental pellicle in vivo and their fate after adsorption to the human enamel surface. Arch Oral Biol 28: 19-27.

8. Hay DI, Carlson ER, Schluckebier SK, Moreno EC, Schlesinger DH (1987) Inhibition of calcium phosphate precipitation by human salivary acidic proline-rich proteins: structure-activity relationships. Calcif Tissue Int 40: 126-132.

9. Levine $\mathrm{M}$ (2011). Susceptibility to dental caries and the salivary prolinerich proteins. Int J Dent Article ID 953412: 13.

10. World Health Organization (2013) Oral Health Surveys basic Methods. Fifth Edition.

11. Vos T, Flaxman AD, Naghavi M, Lozano R, Michaud C, et al. (2012) Years lived with disability (YLDs) for 1160 sequelae of 289 diseases and injuries
1990-2010: a systematic analysis for the Global Burden of Disease Study 2010. Lancet 380: 2163-2196.

12. Selwitz RH, Ismail AI, Pitts NB (2007) Dental caries. Lancet 369: 51-59.

13. Ten Cate JM (2001) What dental diseases are we facing in the new millennium: some aspects of the research agenda. Caries Res 35: 2-5.

14. Touqer-Decker R, van Loveren C (2003) Sugars and dental caries. Am J Clin Nutr 78: 881S-892S.

15. Forssten SD, Björklund M, Ouwehand AC (2010) Streptococcus mutans, caries and simulation models. Nutrients 2: 290-298.

16. Merritt J, Qi F (2012) The mutacins of Streptococcus mutans: regulation and ecology. Mol Oral Microbial 27: 57-69.

17. Karpinski TM, Szkaradkiewicz AK (2013) Microbiology of dental caries. J Biol Earth Sci 3: M21-M24.

18. Bennick A, Madapallimattam G (1983) Immuno-radiometric assays for human salivary acidic proline-rich proteins and their $\mathrm{N}$ - and $\mathrm{C}$-terminal fragments. Arch Oral Biol 28:13-17.

19. Hay DI, Bennick A, Schlesinger DH, Minaguchi K, Madapallimattam G et al. (1988) The primary structures of six human salivary acidic prolinerich proteins (PRP-1, PRP-2, PRP-3, PRP-4, PIF-s and PIF-f). Biochem J 255: 15-21.

20. Gibbons RJ, Hay DI (1989) Adsorbed salivary acidic proline-rich proteins contribute to the adhesion of Streptococcus mutans JBP to apatitic surfaces. J Dent Res 68: 1303-1307.

21. Mandel ID, Bennick A (1983) Quantitation of human saliva acidic proline-rich proteins in oral diseases. J Dent Res 62: 943-945.

22. Burdon RH, Von Knippenberg PH (1985) Practice and theory of enzyme immunoassays. Elsevier, Amsterdam, New York-Oxford.

23. Vieira AR, Modesto A, Marazita ML (2014) Caries: review of human genetics research. Caries Res 48: 491-506.

24. Opal S, Garg S, Jain J, Walia I (2015) Genetic factors affecting dental caries risk. Aust Dent J 60: 2-11.

25. Lenander-Lumikari M, Loimaranta V (2000) Saliva and dental caries. Adv Dent Res 14: 40-47. 